\title{
Siphonodictyal B1 from a Marine Sponge Increases Intracellular Calcium Levels Comparable to the $\mathrm{Ca}^{2+}$-ATPase (SERCA) Inhibitor Thapsigargin
}

\author{
Ulf Bickmeyer • Achim Grube • Karl-Walter Klings • \\ Joseph R. Pawlik • Matthias Köck
}

Received: 8 July 2008 / Accepted: 13 June 2009/Published online: 16 July 2009

(C) Springer Science + Business Media, LLC 2009

\begin{abstract}
Siphonodictyal B1 is a sesquiterpene-hydroquinone isolated from the Caribbean coral reef bioeroding sponge Siphonodictyon coralliphagum. Siphonodictyal B1 increased intracellular calcium levels in neuroendocrine cells (PC12) in the presence and absence of extracellular calcium using Fura-2 as a calcium-sensitive dye. The calcium rise was comparable in amplitude and timing to the application of the sarco-endoplasmic reticulum calcium-ATPase (SERCA) inhibitor thapsigargin from the terrestrial plant Thapsia garganica. The effects of thapsigargin and siphonodictyal B1 on intracellular calcium levels were not distinguishable in pharmacological experiments conducted with caffeine, ryanodine, muscarine, and thapsigargin in calcium-free and calcium-containing buffer, although thapsigargin was effective at lower concentrations. Thapsigargin is a sesquiterpene-lactone and has no structural similarities to siphonodictyal B1. We conclude
\end{abstract}

U. Bickmeyer $(\bowtie) \cdot$ K.-W. Klings

Alfred-Wegener-Institut für Polar- und

Meeresforschung in der Helmholtz-Gemeinschaft,

Biologische Anstalt Helgoland, Kurpromenade 201,

27498 Helgoland, Germany

e-mail: Ulf.Bickmeyer@awi.de

A. Grube $\cdot$ M. Köck

Alfred-Wegener-Institut für Polar- und

Meeresforschung in der Helmholtz-Gemeinschaft,

Am Handelshafen 12,

27570 Bremerhaven, Germany

J. R. Pawlik

Center for Marine Science,

University of North Carolina Wilmington,

5600 Marvin K. Moss Lane,

Wilmington, NC 28409, USA that thapsigargin and siphonodictyal B1 share SERCAs as cellular targets. Siphonodictyal B1 may be involved in the process of bioeroding the calcium carbonate endoskeleton of the scleractinian corals attacked by $S$. coralliphagum.

Keywords Fura- $2 \cdot$ Calcium signaling $\cdot$ Secondary metabolite $\cdot$ Marine sponge $\cdot$ PC12 Thapsigargin . Siphonodictyon coralliphagum

\section{Introduction}

Marine plants, animals, and microorganisms produce a large number and wide variety of secondary metabolites that may play different ecological roles, including defense against predators, prevention of overgrowth, and intraspecific signaling. Sponges are particularly well known as important sources of chemically interesting substances, some of which have unusual structures (for review, see Blunt et al. 2008). Because they are sessile, benthic, and lack motility, many sponges defend themselves against predators by producing deterrent metabolites, such as alkaloids (Pawlik et al. 1995; Assmann et al. 2000).

In our previous studies, sponge-derived anti-predatory alkaloids were shown to disturb cellular signaling by reducing depolarization-induced calcium entry (Bickmeyer et al. 2004, 2007; Bickmeyer 2005). Sarco-endoplasmic reticulum calcium-ATPases (SERCAs) are responsible for the energy dependent flux of $\mathrm{Ca}^{2+}$ into intracellular calcium stores, especially the sarco-endoplasmic reticulum and the Golgi apparatus (Pinton et al. 1998). A sesquiterpenelactone from the terrestrial plant Thapsia garganica "thapsigargin" is known to effectively inhibit SERCAs (Thastrup et al. 1990), which greatly advanced research on cellular calcium signaling. Both thapsigargin and the 
synthetic compound 2,5-di(tert-butyl)hydroquinione (DBHQ), which bind at different sites on the enzyme, are used as a pharmacological tool for investigating calcium stores (Llopis et al. 1991; Xu et al. 2004; Inesi et al. 2005). Other natural products exhibit pharmacological potency as calcium-ATPase inhibitors, such as the plant alkaloid tetrandrine (Bickmeyer et al. 1998), which additionally reduces voltage-dependent calcium entry by slowly inactivating calcium channels as a use-dependent open channel blocker (Weinsberg et al. 1994).

As a class, sesquiterpene-hydroquinones are known for a variety of pharmacological effects, including antiviral (Wright et al. 1991) and antibiotic activity (Tsoukatou et al. 2007), inhibition of interleukin-8 receptors (Patil et al. 1997), and inhibition of tubulin assembly (for review: Sladić and Gašić 2006). In this study, we focused on calcium signaling, keeping in mind that sesquiterpenes such as thapsigargin and some hydroquinones disturb calcium sequestration in cellular stores. Our attention turned specifically to the sesquiterpene-hydroquinone siphonodictyal B1 (Grube et al. 2007), which had previously exhibited some antibiotic activity but which may play a more important ecological role as the major secondary metabolite in the tissue of a sponge noted for bioeroding reef-building corals.

\section{Materials and Methods}

\section{Culture Methods}

PC12 cells from the German Collection of Microorganisms and Cell Cultures were kept in culture medium containing Roswell Park Memorial Institute medium 1640, $10 \%$ fetal calf serum, 5\% horse serum, and 100 units penicillin/streptomycin per milliliter. Cells were cultivated in an incubator at $37^{\circ} \mathrm{C}, 90 \%$ humidity, and $5 \% \mathrm{CO}_{2}$ with regular medium changes twice a week or additionally as necessary. Cells grew in culture flasks and were seeded into petri dishes coated with collagen 1-2 days prior to the experiments.

Fluorimetric Measurements of Intracellular Calcium Levels

Cells were incubated in buffer (in millimolar: $125 \mathrm{NaCl}$, $2.5 \mathrm{KCl}, 1 \mathrm{MgCl}_{2}, 2 \mathrm{CaCl}_{2}, 1.3 \mathrm{NaH}_{2} \mathrm{PO}_{4}, 30$ Glucose, $26 \mathrm{Na}$ HEPES) containing $5 \mu \mathrm{M}$ Fura-2 acetoxymethylester for $30 \mathrm{~min}$ at room temperature $\left(22 \pm 2^{\circ} \mathrm{C}\right)$. The incubation buffer was removed, and cells were washed at least for $20 \mathrm{~min}$. Fluorescence of cells was monitored with an imaging system (Visitron, Puchheim) and a charge-coupled device camera mounted on an inverted microscope (Zeiss Axiovert 100). About 30 PC12 cells were measured simultaneously using "the region of interest" function of the software (Metafluor, Meta Imaging Series). Thirty cells were averaged and considered as $n=1 . n$ is the number of separate dishes used for experiments. All experiments were at least repeated twice. Fluorescence was obtained through an UV objective (Zeiss NeoFluar 20X). Data were collected by division of two images, one obtained at $340 \mathrm{~nm}$, the other at $380 \mathrm{~nm}$ excitation. Chemicals were stored as 50 $100 \mathrm{mM}$ stock solutions in methanol at $4^{\circ} \mathrm{C}$ for experimental use, otherwise, as freeze-dried powder at $-20^{\circ} \mathrm{C}$.

\section{Experimental Design}

The recording chamber, mounted on a microscope, had a volume of $2 \mathrm{~mL}$, and a peristaltic pump was adjusted to $4 \mathrm{~mL} / \mathrm{min}$ exchanging the chamber volume in $30 \mathrm{~s}$. To depolarize the cells, $80 \mathrm{mM} \mathrm{KCl}$ was used (supplemented for $80 \mathrm{mM} \mathrm{NaCl}$ ) in the experimental buffer. Therefore, the depolarization of the cellular membrane potential increased gradually during $30 \mathrm{~s}$ of perfusion. In initial experiments, cells were depolarized three times for $1 \mathrm{~min}$ during the course of a single experiment with the duration of about $60 \mathrm{~min}$. Usually 30 cells were measured simultaneously. Vehicle control experiments using methanol, the solvent necessary to dissolve alkaloids, showed no effect at concentrations lower than $1 \%$. Results are presented as the mean \pm SEM, unless otherwise stated. Statistics and calculations were performed using computer software Prism (Graphpad) and Igor (WaveMetrics).

\section{Sponge Secondary Metabolites and Other Compounds}

The sesquiterpene-hydroquinone siphonodictyal B1 (Fig. 1) was isolated from methanol extracts of the bioeroding sponge Siphonodictyon coralliphagum, growth form Galzinia incrustans, collected by SCUBA at San Salvador in the Bahamas (40-85 ft depth, March 2001, July 2003, and June 2007). The samples were immediately frozen after collection and kept at $-20^{\circ} \mathrm{C}$ until they were freeze-dried. Freeze-dried sponge tissue was crushed with a mill and extracted exhaustively with $\mathrm{MeOH}$ at room temperature under nitrogen atmosphere for $24 \mathrm{~h}$. The yellow-orange-colored crude extract was purified by preparative RP18 high-performance liquid chromatography $\left(\mathrm{MeCN} / \mathrm{H}_{2} \mathrm{O}\right.$ Gradient) using a ProntoSIL Eurobond C18 column (VDS Optilab; $250 \times 20 \mathrm{~mm}, 5 \mu \mathrm{m})$. Collected fractions were immediately freeze-dried to obtain the pure compounds. Other compounds were obtained from Sigma, Merck, Fluka and Molecular Probes. Caffeine was used at a concentration of $40 \mathrm{mM}$, thapsigargin at $5 \mu \mathrm{M}$, muscarine at $100 \mu \mathrm{M}-1 \mathrm{mM}$, and ryanodine at $50 \mu \mathrm{M}$. The solution with B1 and B2 was prepared immediately before the start of the experiment from methanol stock solution. 
Fig. 1 a Chemical structure of thapsigargin, siphonodictyal B1, and siphonodictyal B2. b Efficacy of siphonodictyal B1 and siphonodictyal B2 to increase intracellular calcium levels in percentage of the maximal response (1 min depolarization using $80 \mathrm{mM} \mathrm{K}^{+}$)

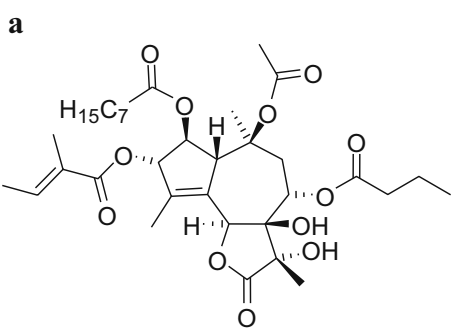

Thapsigargin<smiles>C[C@H]1CCC2C(C)(C)CCC[C@]2(C)/C1=C/c1cc(O)c([O-])c(C=NCC(=O)O)c1OS(=O)(=O)O</smiles>

Siphonodyctial B1

Siphonodyctial B2

b

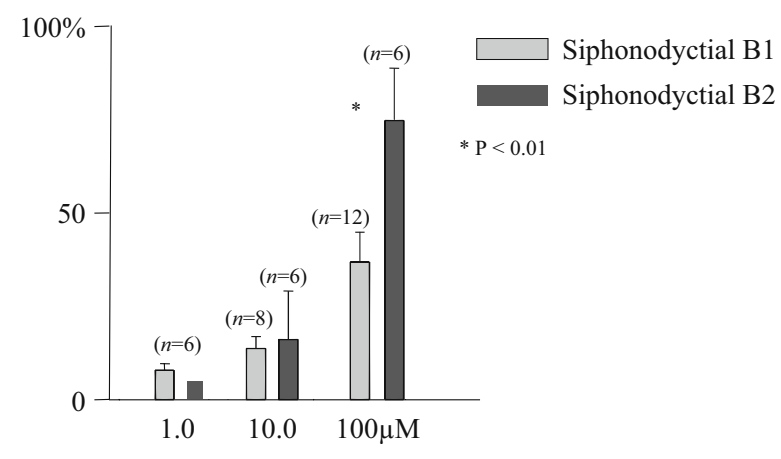

\section{Results}

Because siphonodictyal B1 decomposes to siphonodictyal B2 in water (unpublished results), we tested siphonodictyal B2 for its effect on increasing intracellular calcium levels and found that it was more effective than siphonodictyal B1 at higher concentrations (Fig. 1). For this reason, we took care to prepare fresh solutions of siphonodictyal B1 for each set of experiments to minimize the amount of siphonodictyal B2 in our test solutions.
In experiments using freshly prepared siphonodictyal B1 (Fig. 1), we noted an increase of intracellular calcium $\left(\mathrm{Ca}_{\mathrm{i}}{ }^{2+}\right.$; Fig. 2a) and a clear broadening of voltage operated calcium signals. Further, siphonodictyal B1 increased calcium signals without application of high levels of potassium $\left(\mathrm{K}^{+}\right)$as do some G-protein coupled receptors, or with the application of caffeine or the SERCA inhibitor thapsigargin (Fig. 2). Siphonodictyal B1 and thapsigargin induced a similar pattern of changes in the amplitude, duration, and time course of calcium
Fig. 2 Response of Fura-2 to calcium binding (F340/380) during $3 \times$ stimulation with a high potassium solution $\mathrm{K}^{+}$and control conditions (a), during application of siphonodictyal B1 $(S d, 100 \mu \mathrm{M})$ prior to the second $\mathrm{K}^{+}$stimulation (b), during application of thapsigargin $(5 \mu \mathrm{M}$; c). Plot (d) demonstrates the calcium elevation during of a prolonged siphonodictyal B1 application (10 $\mathrm{min})$
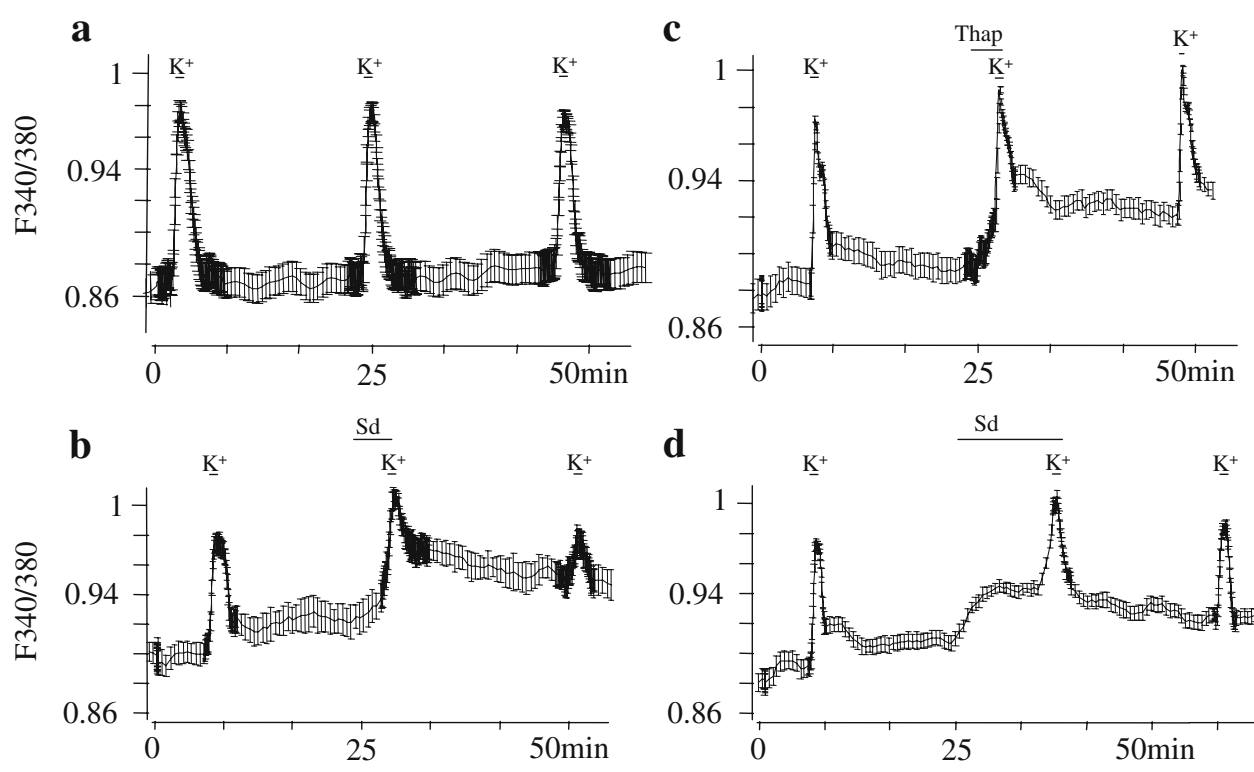
a

Concentration-effect relationship of Sd on voltage operated calcium elevation and baseline calcium levels in \% of control

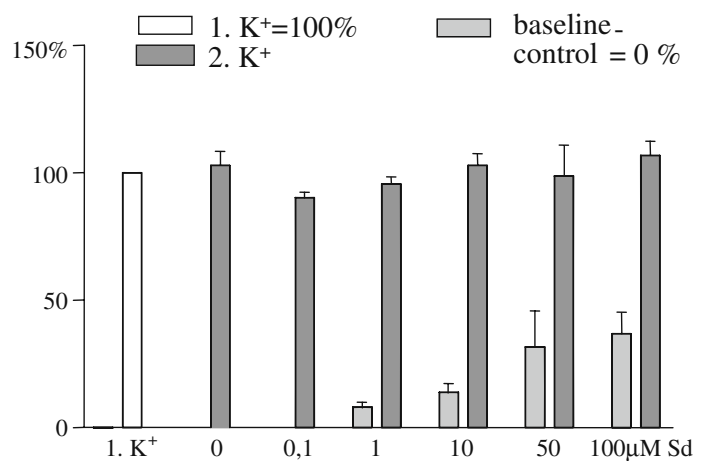

b

Calcium elevation in $\%$ of $\mathrm{K}^{+}$control

in induced by $\mathrm{Sd}$ and thapsigargin

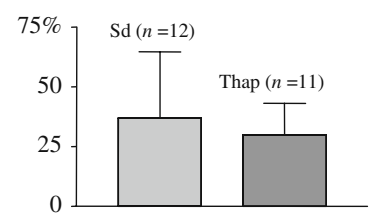

Fig. 3 Concentration-effect relationship of siphonodictyal B1 $(S d$, upper graph) on baseline calcium levels and on $\mathrm{K}^{+}$induced elevation (no effect) and comparison of effects of siphonodictyal B1 $(100 \mu \mathrm{M})$ and thapsigargin (Thap, $5 \mu \mathrm{M}$; lower graph)

changes. Moreover, there was a dose-dependent intracellular calcium elevation induced by siphonodictyal B1 (Fig. 3). The dose-response relationship was greatest at approximately $100 \mu \mathrm{M}$. In all of the experiments that

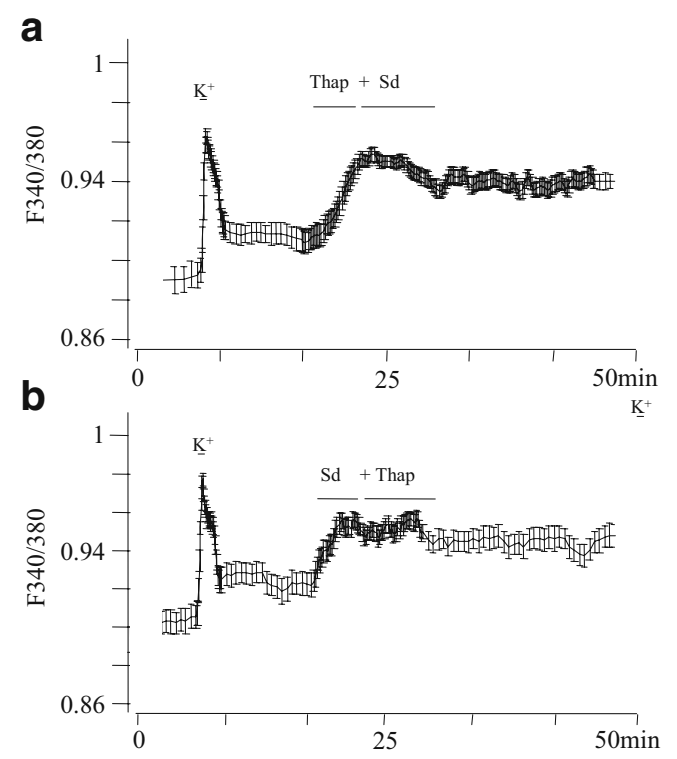

Fig. 4 Application of thapsigargin $(5 \mu \mathrm{M})$ followed by siphonodictyal B1 (Sd, $100 \mu \mathrm{M}$, upper graph) and siphonodictyal B1 followed by thapsigargin (lower graph) followed, we applied siphonodictyal B1 at a concentration of $100 \mu \mathrm{M}$.

Thapsigargin and siphonodictyal B1 both increased intracellular calcium levels in a comparable manner (Fig. 3b). We therefore compared the effects of thapsigargin and siphonodictyal B1 directly by applying the former followed by the latter (Fig. 4a), and in additional experiments, siphonodictyal B1 was followed by thapsigargin (Fig. 4b). Again, the results $(N=3$ each) revealed similar effects of both compounds, with increased calcium levels independent of the sequence of application. We repeated these experiments in calcium-free buffer, thereby demonstrating that siphonodictyal B1 increased intracellular calcium levels at least partly from intracellular stores (Fig. 5). If siphonodictyal B1 and thapsigargin share the same cellular target, the former should reduce calcium responses to caffeine, and particularly, to thapsigargin in calcium-free buffer. In fact, siphonodictyal B1 inhibited thapsigargin-induced calcium elevations as well as thapsigargin inhibited caffeine-induced calcium elevations (Fig. 5). The effects of siphonodictyal B1 on caffeine responses were comparable to thapsigargin (data not shown). In calcium-free buffer, the three compounds increased intracellular calcium levels (Fig. 5) from intracellular stores.

We performed another set of experiments using physiological buffer (containing calcium) because both siphonodictyal B1 and thapsigargin eliminated pharmacological-induced calcium responses in calcium-free solutions. Following stim-

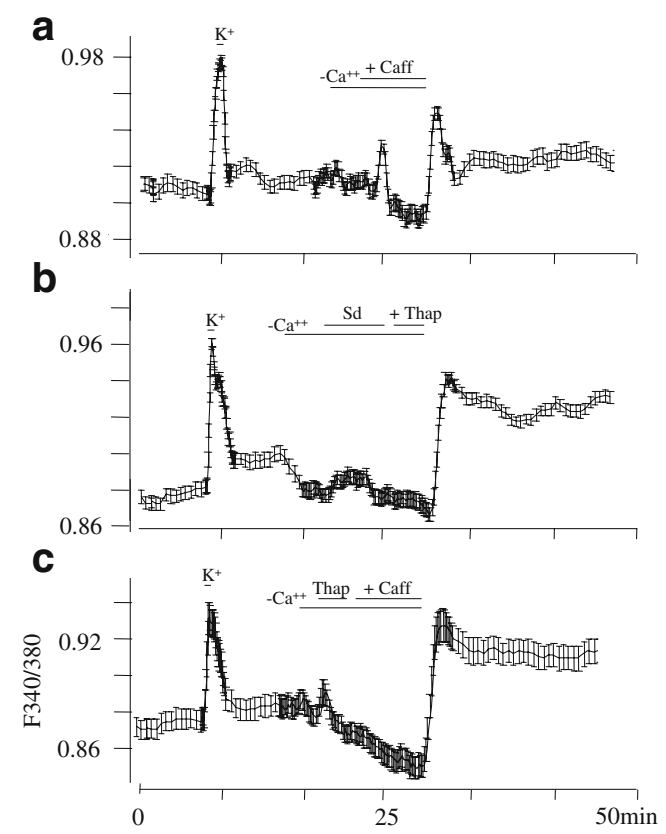

Fig. 5 a Application of caffeine (Caff, $40 \mathrm{mM}$ ) induced a robust response in calcium-free buffer. b Application of siphonodictyal B1 $(S d, 100 \mu \mathrm{M})$ followed by thapsigargin in calcium-free buffer $\left(-\mathrm{Ca}^{2+}\right.$ time bar). c Application of thapsigargin (Thap, $5 \mu \mathrm{M})$ followed by caffeine (Caff, $40 \mathrm{mM}$ ) in calcium-free buffer 
a

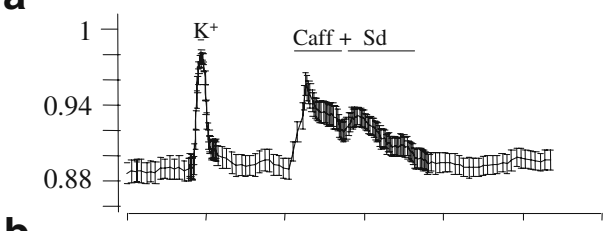

b

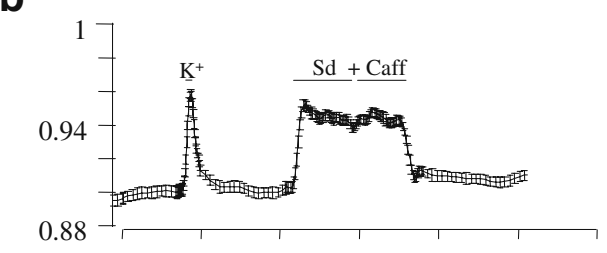

C

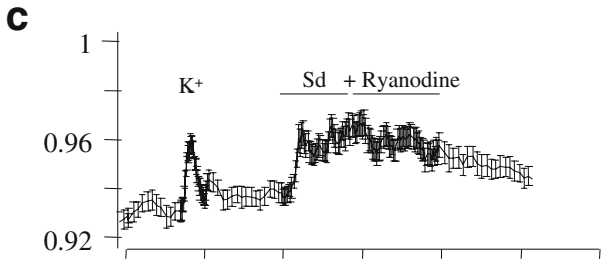

d

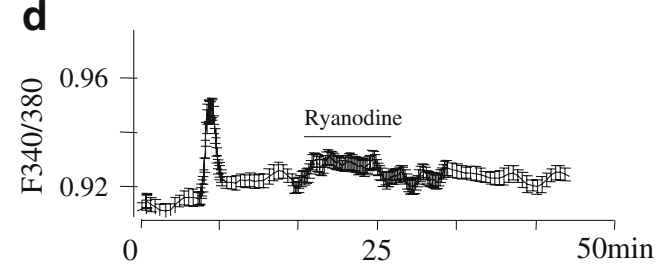

Fig. 6 Stimulation with siphonodictyal B1 $(S d, 100 \mu \mathrm{M})$ following application of caffeine (Caff, $40 \mathrm{mM}$; a), caffeine following siphonodictyal B1 (b), and ryanodine $(50 \mu \mathrm{M})$ following $\mathrm{Sd}(\mathbf{c})$ still reveal a response after previous compound application. d Control experiment using solely ryanodine $(50 \mu \mathrm{M})$

ulation with siphonodictyal B1, caffeine induced a calcium response, and reciprocally, following caffeine stimulation, siphonodictyal B1 induced a response (Fig. 6), indicating that target sites or pathways of the two compounds are not identical. Similar results were obtained using ryanodine following siphonodictyal B1 stimulation, which adds to the siphonodictyal B1 effect. To reveal if InsP3 sensitive calcium stores were stimulated by siphonodictyal B1, we conducted another experiment using muscarine to stimulate muscarinic acetylcholine receptors for activation of the InsP3 second messenger pathway. Following application with siphonodictyal B1, muscarine addition resulted in an additional short calcium elevation $(N=3)$, which suggests that siphonodictyal B1 does not act using the same signaling pathway as muscarine.

In our final experiment, we applied both siphonodictyal $\mathrm{B} 1$ and thapsigargin $(100$ and $5 \mu \mathrm{M})$ simultaneously to inhibit SERCAs and other possible target sites, followed by the application of muscarine. After 10 min of incubation with thapsigargin and siphonodictyal B1, muscarine still induced a small calcium elevation, which was comparable to our previous results using siphonodictyal B1 alone (Fig. 7). Therefore, the application of siphonodictyal B1 as well as the combination of thapsigargin and siphonodictyal B1 resulted in the same effect. The sum of the experimental evidence points to a similar mode of action of SERCA inhibition by thapsigargin and siphonodictyal B1, particularly because the effects of both drugs during multiple experimental approaches are indistinguishable.

\section{Discussion}

The sesquiterpene-hydroquinone siphonodictyal B1 increases intracellular calcium levels in PC12 neuroendocrine cells in the presence and absence of extracellular calcium, evidence of either induced release or inhibited uptake of calcium from intracellular calcium stores. InsP3- as well as ryanodine-receptor activation was still possible after incubation with siphonodictyal B1, indicating alternative cellular targets of siphonodictyal B1. Siphonodictyal B1 inhibits the response to thapsigargin (and to other calcium releasing compounds) in calcium-free buffer, suggesting a possible depletion of intracellular calcium stores, and siphonodictyal B1 mimics the effects of thapsigargin in all of our experiments. Because the effects of both siphonodictyal B1 and thapsigargin are indistinguishable, we assume that they

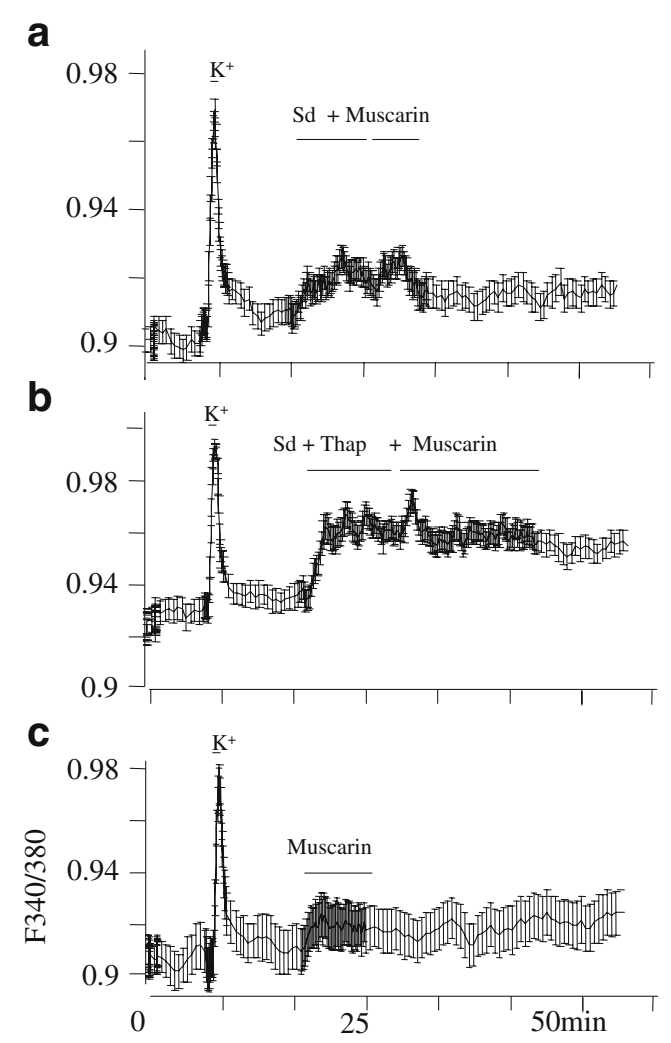

Fig. 7 a Muscarin $(500 \mu \mathrm{M})$ induces still a calcium response following siphonodictyal B1 $(S d, 100 \mu \mathrm{M}$; b) as well as siphonodictyal B1 $(100 \mu \mathrm{M})$ and thapsigargin (Thap, $5 \mu \mathrm{M})$ together. c Control experiment using solely muscarin $(500 \mu \mathrm{M})$ 
share a similar mode of action in the inhibition of SERCAs. Additionally, the chemical structure of other SERCA inhibitors like DBHQ is related to siphonodictyal B1.

The slow degradation of siphonodictyal B1 to B2 in aqueous solution may have played a role in our results, because siphonodictyal B2 caused a greater intracellular calcium elevation after application. This may be explained by the more lipophilic structure of siphonodictyal B2 compared to B1. The latter includes a zwitterionic structure with a protonated imine and phenolat ion (see Fig. 1), which makes siphonodictyal B1 clearly more polar than siphonodictyal B2. Therefore, siphonodictyal B2 has improved permeability through cell membranes, resulting in a higher intracellular concentration. Since only very small quantities of material were available, further characterization was not possible.

While siphonodictyal B1 showed a concentrationdependent increase in intracellular calcium levels in a reproducible fashion and a clear pharmacological profile, we cannot rule out the possibility that small amounts of siphonodictyal B2 were present during the experiments.

The molecular target site of thapsigargin at SERCAs has recently been elucidated by $\mathrm{Xu}$ et al. (2004). We cannot discriminate target sites at the enzyme on the basis of our experiments, but inhibition of SERCAs is the most probable explanation for the reported effects of siphonodictyal B1.

Siphonodictyal B1 is present as a main metabolite of crude sponge extract in $S$. coralliphagum, suggesting that it has some adaptive role in the biology of the sponge. While it has some minor antimicrobial activity (Grube et al. 2007), siphonodictyal B1 is not an effective chemical defense against fish predators (unpublished results). Instead, siphonodictyal B1 may be involved offensively in the process of bioeroding the skeletons of reef-building corals or defensively in preventing corals from overgrowing and smothering the sponge. In the latter case, siphonodictyal B1 may act to inhibit calcium-ATPase, which corals use to sequester and build their limestone skeletons (Al-Horani et al. 2003). Whether corals possess ATPases sensitive to siphonodictyal B1 remains to be elucidated.

Acknowledgements Funding for sponge collections was provided by the National Science Foundation, Biological Oceanography Program (OCE-0550468), including UNOLS ship support on the RV Seward Johnson. We thank the government of the Bahamas for permission to perform research and collect samples in their territorial waters. We are grateful to the students of Biology at the University of Hamburg and Janine Peikert, Robert Ihns, and Sven Falke for their sound help.

\section{References}

Al-Horani FA, Al-Moghrabi SM, de Beer D (2003) The mechanism of calcification and its relation to photosynthesis and respiration in the scleractinian coral Galaxea fascicularis. Mar Biol 142:419426

Assmann M, Lichte E, Pawlik JR, Köck M (2000) Chemical defenses of the Caribbean sponges Agelas wiedenmayeri and Agelas conifera. Mar Ecol Prog Ser 207:255-262

Bickmeyer U (2005) Bromoageliferin and dibromoageliferin, secondary metabolites from the marine sponge Agelas conifera, inhibit voltage-operated, but not store-operated calcium entry in $\mathrm{PC} 12$ cells. Toxicon 45:627-632

Bickmeyer U, Weinsberg F, Müller E, Wiegand H (1998) Blockade of voltage-operated calcium channels, increase in spontaneous catecholamine release and elevation of intracellular calcium levels in bovine chromaffin cells by the plant alkaloid tetrandrine. Naunyn Schmiedebergs Arch Pharmacol 357:441-445

Bickmeyer U, Drechsler C, Köck M, Assmann M (2004) Brominated pyrrole alkaloids from marine Agelas sponges reduce depolarizationinduced cellular calcium elevation. Toxicon 44:45-51

Bickmeyer U, Grube A, Klings KW, Köck M (2007) Disturbance of voltage-induced cellular calcium entry by marine dimeric and tetrameric pyrrole-imidazole alkaloids. Toxicon 15:490-497

Blunt JW, Brent R, Copp BR, Munro MHG, Northcote PT, Prinsep MR (2008) Marine natural products. Nat Prod Rep 25:35-94

Grube A, Assmann M, Lichte E, Sasse F, Pawlik JR, Köck M (2007) Bioactive metabolites from the Caribbean sponge Aka coralliphagum. J Nat Prod 70:504-509

Inesi G, Hua S, Xu C, Ma H, Seth M, Prasad AM, Sumbilla C (2005) Studies of $\mathrm{Ca}^{2+}$ ATPase (SERCA) Inhibition. J Bioenerg Biomembranes 37:6

Llopis J, Chow SB, Kass GE, Gahm A, Orrenius S (1991) Comparison between the effects of the microsomal $\mathrm{Ca}(2+)$-translocase inhibitors thapsigargin and 2,5-di-(t-butyl)-1,4-benzohydroquinone on cellular calcium fluxes. Biochem J 277:553-556

Patil AD, Freyer AJ, Killmer L, Offen P, Carte B, Jurewicz AJ, Johnson RK (1997) Frondosins, five new sesquiterpene hydroquinone derivatives with novel skeletons from the sponge Dysidea frondosa: inhibitors of interleukin-8 receptors. Tetrahedron 53:5047-5060

Pawlik JR, Chanas B, Toonen RJ, Fenical W (1995) Defenses of Caribbean sponges against predatory reef fish I. Chemical deterrency. Mar Ecol Prog Ser 127:183-194

Pinton P, Pozzan T, Rizzut R (1998) The Golgi apparatus is an inositol 1,4,5-trisphosphate-sensitive $\mathrm{Ca}_{2}^{+}$store, with functional properties distinct from those of the endoplasmic reticulum. EMBO J 17(18):5298-5308

Sladić DI, Gašić MJ (2006) Reactivity and biological activity of the marine sesquiterpene hydroquinone Avarol and related compounds from sponges of the order dictyoceratida. Molecules 11:1-33

Thastrup O, Cullen PJ, Drobak BK, Hanley MR, Dawson AP (1990) Thapsigargin, a tumor promoter, discharges intracellular $\mathrm{Ca}$ stores by specific inhibition of the endoplasmic reticulum $\mathrm{Ca}$ ATPase. Proc Natl Acad Sci U S A 87:2466-2470

Tsoukatou ML, Maréchal JP, Hellio C, Novaković I, Tufegdzic S, Sladić D, Gašić MJ, Clare AS, Vagias C, Roussis V (2007) Evaluation of the activity of the sponge metabolites avarol and avarone and their synthetic derivatives against fouling micro- and macroorganisms. Molecules 12:1022-1034

Weinsberg F, Bickmeyer U, Wiegand H (1994) Effects of tetrandrine on calcium channel currents of bovine chromaffin cells. Neuropharmacology 33:885-890

Wright AE, Rueth SA, Cross SS (1991) An antiviral sesquiterpene hydroquinone from the marine sponge Strongylophora hartmani. J Nat Prod 54:1108-1111

Xu C, Ma H, Inesi G, Al-Shawi MK, Toyoshima C (2004) Specific structural requirements for the inhibitory effect of thapsigargin on the $\mathrm{Ca}^{2+}$ ATPase SERCA. J Biol Chem 279(17):17973-17979 